\title{
CAPD 療法における経過不良例の生活環境とストレスについて
}

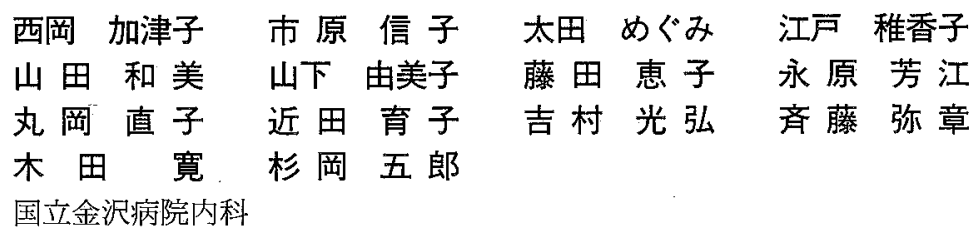

key words : CAPD, ストレス，食事療法，生活環境，家族の協力

〈要旨〉

CAPD 導入時には積極的適応の基準を満たし，導入後は良好な経過が期待されると考えられた 15 例のうち，心不 全・溢水および腹膜炎を繰り返した 6 例を I 群, 経過が良好であった 9 例をII群として, 生活環境およびその変化か ら受けるストレスに対処する能力について検討した。

性・年齢・職業および生活環境についてみると, I 群は独身男性, 自営業（各2名）と幼児をもつ若年女性，会社 社長（各 1名）であった．またI群では，30４0 代の働き盛りの男性（3名）と血液透析から移行した男性（1名） と中年の専業主婦（5名）であった。

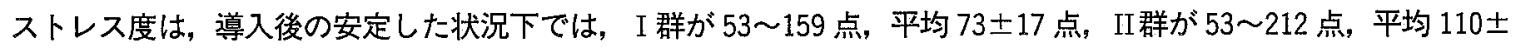
12 であった。 しかし I 群では合併症のおきる直前に $118 \sim 480$ 点, 平均 $295 \pm 48$ 点に上昇した $(p<0.005)$. ストレス 增大の原因として, CAPD における最大の支援者である家族の入院, 転職, 職場の配置転換, 退職, 住居の新築, 育 児および経済的困難などのさまざまなケースがみられた。

食事管理能力は，II群の中年の専業主婦で高く，これは子供がすでに成長しており食事療法に対して専念できるた めと考えられた。一方, I 群の独身男性や育児に追われている若年女性では劣っていた。これらの症例では, 麵類を 多く摄ったために，蛋白質の摂取が少なかったり，外食の頻度も高く，塩分制限も守られなかった。

家族支援については，I 群に比べてII群でより協力的であった $(\mathrm{p}<0.05)$.

今回の研究により，永続的な自己管理が必要な CAPD 潦法が，患者に大きな精神的負担となっており，これに生活 環境の変化から受ける新たなストレスが加わると, 食事管理・バッグ操作に集中できなくなり，溢水・腹膜炎などの 合併症を誘発する可能性が示された。

\section{Life circumstances and psychological stress in CAPD patients with unstable clinical course}

Katsuko Nishioka, Nobuko Ichihara, Megumi Ohta, Chikako Edo, Kazumi Yamada, Yumiko Yamashita, Keiko Fujita, Yoshie Nagahara, Naoko Maruoka, Ikuko Konda, Mitsuhiro Yoshimura, Yahumi Saito, Hiroshi Kida, Gorou Sugioka

Department of Internal Medicine, of Kanazawa National Hospital

In an attempt to evaluate the influences of psychological stress induced by changes in a patient's life circumstances, as well as indispensable management of CAPD, we investigated 15 patients undergoing CAPD who fulfilled the criteria of positive indications for entry into the CAPD program and were expected to follow a stable clinical course. They were divided into 2 groups. Patients belonging to group I had recurrent attacks of congestive heart failure (CHF) and peritonitis and group II patients had a stable clinical course without such complications. The former consisted of 2 unmarried men, 2 men having their own businesses, a young woman with an infant, and

西岡加津子 国立金沢病院内科＝920 金沢市石引 3-1-1（0762-62-4161） 
the owner of a company and the latter included one unmarried man who had undergone hemodialysis one year before, 3 married men having their own businesses and 5 middle aged housewives.

The psychological stress value estimated using the Social Readjustment Rating Scale of Homes and Rahe was $73 \pm 17(53 \sim 159)$ in group I and $110 \pm 12(53 \sim 212)$ in group II just after the initiation of CAPD. However, in group I patients, it was increased to $295 \pm 48(118 \sim 480)$ just before the complications occurred $(p<0.005)$. The causes of an increase in this value were as follows ; admission of a family member taking care of the patient, a change in the patient's occupation, reshuffling, retirement, building of a new house, child care and decreased income.

Middle aged housewives could manage their diet and CAPD well, because their children had already grown up and did not need to be taken care of. However, two young unmarried men and the young woman with an infant often ate out and did not restrict salt intake and adhere to a low protein diet.

Technical support and active participation in the patient's treatment by family members were not adequate in group I patients as compared to group II patients $(\mathrm{p}<0.05)$.

These results suggest that psychological stress caused by changes in life circumstances, as well as by CAPD itself which requires lifelong management, disturbed diet control and handling of bag exchange, and thus might have induced complications.

\section{緒言}

CAPD の積極的適応の基準として，良好な腹膜機能， 自己管理能力，積極的な社会復㷌指向，強い意志，家族 の理解と協力, 社会的環境の受け入れ,ならびに 60 歳を 越えないことなどが指摘されている11.しかし，一旦 CAPD に導入されると, 生命維持のため一日も欠かすこ となく永続的に自己管理を行わねばならないことが，本 人ばかりではなく家族にも，大きな精神的負担となる ${ }^{2)}$. 当施設において，導入時にこのような積極的適応の基準 を満たし，導入後の良好な経過が予測されたにも拘わら ず，頻回に心不全や腹膜炎を繰り返し，導入後の経過が 不良となった症例を経験した。そこで, 今回はこのよう な症例の生活環境およびその変化から受けるストレスに 対処する能力などについて経過良好例と対比し, 検討し たので報告する。

\section{対象}

CAPD 導入時に, 積極適応基準を満たしたと考えられ た 15 例を対象とし, 導入後の経過により 2 群に分けた。 内訳は水分・塩分制限を守らなかったために起こった心 不全，あるいはバッグ操作ミスによると考えられる腹膜 炎を年, 平均 1.0 回以上招こし，経過が不良と判定され た 6 例 ( I 群) と, 腹膜炎・心不全を一度も起こしたこ とがなく，良好な経過をたどった 9 例 (II群) である (表 1). なお, 性別, 導入時の年齢, 導入からの期間, 原疾 患, 除水量, 尿量については両群間で差がなかった。 方法

両群について, 職業, 生活環境, ストレス度, 生化学 的検查执よび栄養状態, 食事調査による食事管理能力の 評価, および家族の支援状況について調査し, 心不全・
腹膜炎の発症との関連性を検討した。このうちストレス 度については Holmes と Rahe ${ }^{3)}$ の社会再適応尺度（表 2）を用い, 患者の周囲に扔きた出来事から受けるスト レス度を算出した。

食事管理能力は, (1) 3 か月ごとに実施している食事調 查に打ける献立の正確な記入, (2) 総カロリー摄取量 (適 正力ロリ一に対しての $\pm 20 \%$ 以内)，(3)塩分制限 (7g 以 下)，(4) 蛋白質摄取量 (1.5 g/kgの $10 \%$ 以内)，(5)外食 の頻度（週 3 回以上は不良），(6) 自己管理ノートの記入 （毎日の体重・除水量を記入していること）について，良 好と判断された項目が 5 項目以上のものを良好， $3 \sim 4$ 項目のものを普通， 2 項目以下のものを不良とした。 た，家族の支援状況は，外来通院や家庭訪問により，本 人および家族と直接面談して評価した。項目は, (1) 適任 な調理者, (2)バッグ交換ができる人, (3)カテーテルケア ができる人, (4)バッグ交換に使用する部屋の確保, (5) 経 済的な補償（本人が病気で倒れても，収入面で困ること はないか)，の 5 項目である. 5 項目すべてを満足するも のを良好， $3 \sim 4$ 項目のものを普通， 2 項目以下のもの を不良とした。

なお, 統計学的処理には, Wilcoxon の順位和検定を 行った。

\section{結果}

1. 症例提示（経過不良例）

症例 1 : 導入時年齢が 24 歳の独身男性で, 父親と祖母 の 3 人家族である(図 1 )。導入 2 年目までは, バッグ操 作ミスで腹膜炎を 4 回起こしたが，家族の協力，ディス コネクトシステムへの変更により以後は順調に経過し た。ところが，導入 5 年目に食事・精神面に扔ける最大 
表 1 患者のプロフィール

\begin{tabular}{|c|c|c|c|c|c|c|}
\hline & 症例 & 年齢 & 性別 & CAPD 歴 & 職業 & 家族構成 \\
\hline \multirow{4}{*}{$\begin{array}{l}\text { 経 } \\
\text { 過 } \\
\text { 丕 } \\
\text { 良 }\end{array}$} & 1 & 24 & 男. & 75 か月 & 会社員 $\rightarrow$ 無職 & 祖母 (入院中), 父 \\
\hline & 2 & 53 & 男 & 22 加月 & 電気工事会社社長 & 母, 妻, 子 (22 歳, 17 歳, 14 歳) \\
\hline & 3 & 40 & 男 & 38 加月 & 建築設備業（自営） & 妻 \\
\hline & 4 & 56 & 男 & 44 か月 & 清掃業（自営） & 妻, 子（25 歳） \\
\hline \multirow{2}{*}{$\begin{array}{c}I \\
\text { 群 }\end{array}$} & 5 & 26 & 男 & 13 か月 & ホテル従業員 & 一人暮らし \\
\hline & 6 & 25 & 女 & 30 か月 & 主婦（育児に専念） & 夫, 幼児 \\
\hline \multirow{5}{*}{$\begin{array}{l}\text { 経 } \\
\text { 過 } \\
\text { 息 } \\
\text { 恏 } \\
\text { 例 }\end{array}$} & 7 & 43 & 男 & 33 加月 & 電気機器販売 & 妻, 子 (17 歳, 11 歳) \\
\hline & 8 & 37 & 男 & 10 分月 & 銀行員 & 一人暮らし \\
\hline & 9 & 37 & 男 & 34 か月 & 飲食店経営 & 妻, 幼览 \\
\hline & 10 & 46 & 男 & 22 出月 & 寝具店経営 & 妻, 子（20 歳, 17 歳） \\
\hline & 11 & 47 & 女 & 54 か月 & 主婦 & 夫，子（23 歳） \\
\hline \multirow{4}{*}{$\begin{array}{c}\text { II } \\
\text { 群 }\end{array}$} & 12 & 57 & 女 & 51 分月 & 主婦 & 長男夫婦, 孫 \\
\hline & 13 & 32 & 女 & 48 か月 & 主婦 & 母, 夫 \\
\hline & 14 & 43 & 女 & 23 加月 & 主婦 & 姑, 夫, 子 (18 歳) \\
\hline & 15 & 45 & 女 & 46 か月 & 主婦 & 夫, 長男夫婦, 次男 (23 歳), 孫 \\
\hline
\end{tabular}

表 2 社会再適応評価尺度

\begin{tabular}{l|c}
\multicolumn{1}{c|}{ 生活上の出来事 } & ストレス度 \\
\hline 配偶者の死亡 & 100 \\
離婚 & 73 \\
親密な家族の死亡 & 63 \\
自分の病気あるいは障害 & 53 \\
結婚 & 50 \\
失業 & 47 \\
家族の病気 & 44 \\
新しい仕事への再適応 & 39 \\
経済状態の悪化 & 38 \\
異なった仕事への配置換え & 36 \\
借金 (100万円以上) & 31 \\
仕事上の責任の変化 & 29 \\
生活状況の変化 & 25 \\
住居が変わること & 20 \\
睡眠習慣の変化 & 16 \\
\hline
\end{tabular}

(Holmes と Rahe の社会再適応評価尺度 より抜枠)

の支援者であった祖母が入院したため，この頃より外食 が多くなり，塩分制限が守られず，全身浮腫が出現し， 溢水状態となった。加えて, うつ状態が現われ, 精神科 で治療を受けた。さらに転職をしたこともあって，この 時期にストレス度は 480 点にもなった。再びバッグ操作 ミスによる腹膜炎を繰り返すため, 血液透析への変更を 予定していたところ, 直前に重症腹膜炎を起こし死亡し た.

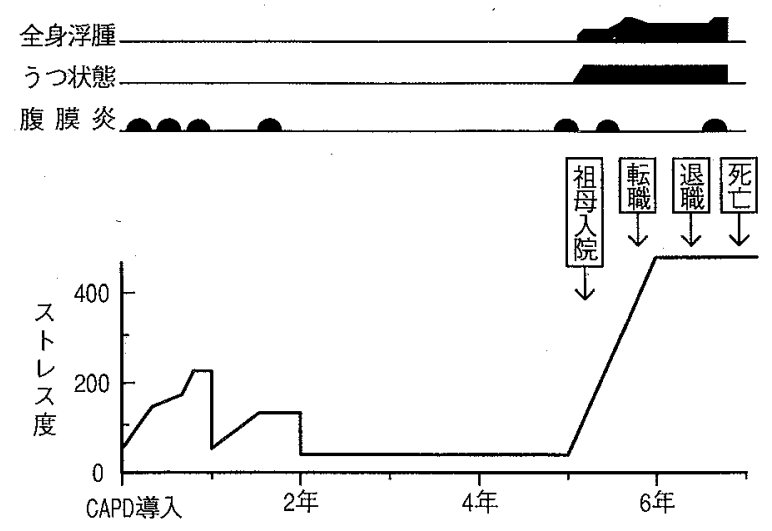

図 1 症例 1 （24歳, 独身男性）の臨床経過

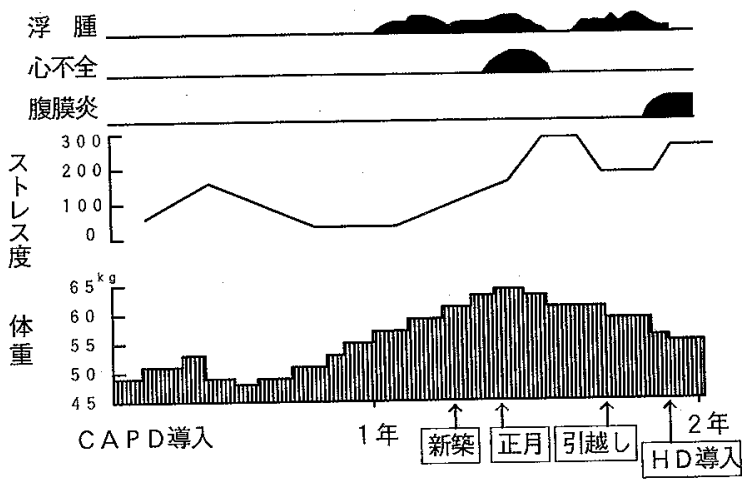

図 2 症例 2 (53 歳男性, 会社社長) の臨床経過 
表 3 生化学的検查扔よび栄養状態

\begin{tabular}{ccccc}
\hline & T.P (g/d $l)$ & Alb $(\mathrm{g} / \mathrm{d} l)$ & $\begin{array}{c}\text { 必要カロリー } \\
\text { 拱取率 }(\%)^{*}\end{array}$ & $\begin{array}{c}\text { 蛋白摄取率 } \\
(\%)^{*}\end{array}$ \\
\hline I 群 (不良例) & $6.6 \pm 0.9$ & $3.8 \pm 0.2$ & $86 \pm 7$ & $78 \pm 7$ \\
\hline II群 (良好例) & $6.7 \pm 0.2$ & $4.3 \pm 0.1$ & $93 \pm 5$ & $88 \pm 2$ \\
\hline $\mathrm{P}$ & $\mathrm{NS}$ & $<0.025$ & $\mathrm{NS}$ & $\mathrm{NS}$ \\
\hline *標準体重から求めた適正カロリーに対する割合 & &
\end{tabular}

症例 $2: 53$ 歳の会社社長で導入直前に転院してきた 患者である (図 2 ). 知的能力も高く, 入院中の指導内容 の理解も良く, また妻も協力的で食事内容の調查結果も 良好であった. しかし, 導入 1 年後より会社の仕事が忙 しくなり，これにマイホームの新築準備が加わったこと が誘因となって, 水分・塩分制限を守らなくなり, 体重 増加・浮腫が出現した．外来受診のたびに食事指導をし たが，改善されず，さらに不潔な場所でのバッグ操作を 行うようになった。最終的には引越しの最中にほこりの 中でしたバッグ交換が原因と考えられる重症腹膜炎を起 こし，血液透析へ移行した。

2 . 性・年秚令・職業および生活環境

I 群の 20 代には，独身で一人暮らしの男性が 2 人， 2 歳の幼児の育児に追われている主婦が 1 人 (表 1 )，また 40～50 代には自営業あるいは会社社長で，子供はいずれ も成人した患者が 3 人いた。 II群の男性 3 人は $30 \sim 40$ 代 の働き盛りで, 子供は小学生あるいは高校生であり, 患 者の妻はいずれも専業主婦であった。1 人の男性は，4 年間血液透析をしていた後, CAPD に移行した症例で あった。また 5 人の中年女性は専業主婦で，いずれも子 供はすでに成人していた。

\section{3 。ストレス度}

I 群では，導入後の安定した時期でのストレス度は 53〜159 点, 平均 $73 \pm 17$ 点であったが, 合併症の起きる 直前, 導入より平均 $24 \pm 4$ か月後には $118 \sim 480$ 点, 平均 $295 \pm 48$ 点へと有意に上昇していた $(p<0.005)$. 具体的 な出来事についてみると, 先に提示した症例にみられた ものの他に, 息子の結婚式, 自営業の経営がうまくいか ず経済的困難に遭遇したもの, 職場の配置換えのため仕 事の内容が変わったなどであった。

一方, II群では 53〜212 点, 平均 $110 \pm 12$ 点で, I 群 の合併症の起きた時期と同じ頃の, 導入より平均 $24 \pm 4$ か月後でも $53 \sim 159$ 点, 平均 $103 \pm 17$ 点と変化がみられ ず，また I 群の合併症直前のストレス度と比べて有意に 低加た $(\mathrm{p}<0.005)$.

4. 生化学的検査および栄養状態

I 群とII群において，総蛋白・血清アルブミン・必要 カロリー摂取率・蛋白掑取率・腹膜機能について比較・
検討した（表 3 ).

総蛋白においては，有意差はなかった。血清アルブミ ンは, I 群では $3.8 \pm 0.2 \mathrm{~g} / \mathrm{d} l$, II群では $4.3 \pm 0.1 \mathrm{~g} / \mathrm{d} l$ で あり，I 群が有意に低かった $(\mathrm{p}<0.025)$ 。必要カロリー 摂取率・蛋白摄取率においては，両群において有意差は なかったが，I 群のほうが低い傾向にあった．腹膜機能 に関しては, 全例とも腹膜平衡試験 $(\mathrm{PET})^{4)}$ を行い, low あるいは high average で, 両群間で差はみられなかっ た。

\section{5. 食事管理能力の評価}

I 群では, 良好 1 名 (17\%), 普通 3 名 (50\%), 不良 2 名 (33\%) であり, II群では, 良好 6 名 (67\%), 普通 2 名 (22\%), 不良 1 名 (11\%) であった。両群の間には 差はなかったが, II群のほうがI群よりも良好な傾向に あった。とくにI群の独身男性では外食の頻度が多く， 塩分制限が守られなかった。 また 20 代の女性では, 簡単 に調理しやすく，口あたりのよい麵類に偏り，蛋白掑取 が不足していた。一方, II群の自ら食事を作れる中年女 性の 5 例では, うち 4 例が良好であった。

\section{6. 家族の支援状況}

I 群では，普通 4 名 (67\%)，不良 2 名 (33\%) であり， II群の良好 4 名 (44\%), 普通 5 名 (56\%) に比べて, 家 族支援の程度は，I 群のほうが不良であった $(\mathrm{p}<0.05)$.

\section{考察}

提示した 2 例の経過不良例についてみると, 症例 1 で は祖母の入院による支援者の欠如, 転職による生活環境 の変化がストレスとなり,これらが湓水・腹膜炎の誘因 となったものと考元られた。また症例 2 は, 導入直前に 転院してきた患者で，医療スタッフが性格・食生活の把 握を十分に行えなかったことに加え，仕事，自宅の新築 などで多忙となり，体重の管理やバッグ交換が扔ろとか になったことが脱落の誘因であると推測された。

I 群では，経過不良となる直前のストレス度は，導入 後で安定した時期の平均 $73 \pm 17$ 点から $295 \pm 48$ 点と著 しく増加していた，この点に関し，健康人に抢いては， ストレス度の 1 年間の合計が 300 点以上になると, 約 $80 \%$ の症例に健康障害が起きるといわれている5 に CAPD では，他の疾患の治療に比べて，バッグ操作・ 
食事管理など自己管理を要するという点で, CAPD 自体 が，患者にとってはすでに大きな精神的負担となってい る。従って，このような每日の自己管理自体から受ける ストレスに加えて, 生活環境の変化により新たなストレ スが加わると，どうしても自己管理に対する集中力が低 下しやすいものと考元れる。つまり，ストレスをいか に克服するかが CAPD を長期に維持していく上で重要 な鍵であり，そのためには，時間をかけて話し合い，精 神的ストレスを医療スタッフに伝えてくれるよう誘導 するような働きかけが必要なものと考えられる。また， ストレスが増強していると判断された際には, それに対 する対策についての助言を行うとともに，食事管理ある いはバッグ交換操作などが甘くならないように，患者の みならず支援者に対しても指導していくことが必要であ る。

ところで, CAPD 導入前からの患者の職業・生活環境 についてみると, 経過良好例では, 自ら食事を作ること ができる中年の専業主婦が多く，子供もすでに成長して いることから食事療法に十分専念できるため, 管理がう まくできているものと思われた。一方, 経過良好の 30〜 40 代の既婚男性に関しては, 仕事への意欲と子供に 対する責任感が強く,これが CAPD を継続していく上で 必要な緊張感を維持させていたものと推測された。これ に対し, 経過不良例は, 育児に追われている若い女性, 一人暮らしの男性, 仕事偏重になっていた中年男性例で あった。幼児をもつ若年女性は，子供の残り物を食べた り，簡単に食事を済ませてしまったり，また一人暮らし の男性は，外食が多くなる傾向にあった，このような生 活環境を有する例では, 軽いストレスが加わっても, そ のために食事療法が扔ろそかになってしまう可能性が高 いものと考元られた。従って, CAPDへの導入を決定す る前に，バッグ交換の操作能力のみにとらわれず，本人 の食事に対する意識，生活環境などを十分に調査する必 要があるものと思われる. そして, ストレスに弱い生活 環境をもともと有する患者にやむを得ず CAPD を導入
しなければならない場合には，食事を作ってくれる家族 との同居を勧めたり，本人および家族に対して偏食傾向 に宿ることの危険性を十分説明し,できるかぎり未然に 予防できるよう指導していきたいと考えている.

\section{結論}

CAPD 導入当初は良い適応と考えられたにも拘わら ず，心不全・溢水抢よび腹膜炎により経過が不良となっ た 6 例を経験した。これらの症例は，独身男性の一人暮 らし，育児，仕事偏重などもともと食事療法をおろそか にしやすい状況下にあり，これに生活環境の変化などの ストレスが加わったことが誘因となったものと推測され た。

以上より，患者の生活環境・食生活を十分に見極めた 上でCAPD を導入し，このような症例にはとくに食事・ 家族の協力についてより行きとどいた指導を行うことが 重要であると考えられた。

\section{文献}

1）川口良人：CAPD の適応，患者選択および評価。 CAPD ガイドライン医療者用（在宅自己腹膜灌流法 マニュアル等作成委員会編), p 53-59, 財団法人 総 合健康推進財団, 東京, 1992

2) 福島泰子, 小山昌子, 明田川正子, 金井睦子, 星野 貢：CAPD は患者にどのようなストレスを与えて いるか.臨床透析 $8: 61-64,1992$

3) Holmes $T H$, Rahe $\mathrm{RH}$ : The social readjusting rating scale. J Psychosom Res 11 : 213-218, 1967

4) Twardowski ZJ, Nolph KD, Khanna R, Prowant BF, Ryan LP, Moore HL, Nielsen MP: Peritoneal equilibration test. Peritoneal Dialysis Bulletin 7 : 138-147, 1987

5）井上幸子, 平山朝子, 金子道子：ストレスと健康障 害と看護. 看護学大系 第 12 巻 成人の看護(井上幸 子，平山朝子，金子道子編), p 297-299, 日本看護協 会出版会, 東京, 1991 